\title{
Virtual Reality-based Interventions for Patients with Paranoia
}

\section{Elham Monaghesh}

Tabriz University of Medical Sciences

Taha Samad-Soltani

Tabriz University of Medical Sciences

Sara Farhang ( $\sim$ s.farhang@umcg.nl)

Universitair Medisch Centrum Groningen https://orcid.org/0000-0001-8552-138X

\section{Research article}

Keywords: Virtual reality, Psychosis, Paranoia, Schizophrenia, treatment

Posted Date: October 5th, 2020

DOI: https://doi.org/10.21203/rs.3.rs-69984/v1

License: (c) (i) This work is licensed under a Creative Commons Attribution 4.0 International License. Read Full License 


\section{Abstract}

Background: Paranoia is an important psychiatric symptom with an important effect on daily life. Virtual reality (VR) based treatments are suggested as an effectual treatment for patients with paranoia, facilitating learning. To our knowledge, there is a lack of systematic reviews to evaluate VR-based treatment as a treatment for paranoia or paranoid delusions. This study aimed to review reports that investigate VR-based treatment as a treatment for patients with paranoia.

Methods: Studies published up to 20/07/2020 about VR-based interventions for the treatment of patients with paranoid delusions or paranoia were reviewed in five databases including PubMed, Embase, Web of Science, PsycINFO, and Scopus.

Results: From the total of 252 initial searches, 6 were included in the study based on inclusion criteria. Four studies were performed as randomized controlled trials and two were before-after studies. All of them showed positive results in the main target, including increased social participation, reduced anxiety, and suspicious ideas and paranoid symptoms.

Conclusion: VR-based interventions are effective treatments. Although the use of VR technology is limited for a variety of reasons, including the cost, it improves symptoms in patients with paranoia.

\section{Background}

Psychotic disorders are considered severe mental health problems leading to abnormal thoughts and conception (1). The term refers to a spectrum of disorders that is one of the major causes of long-term disability worldwide (2). One important feature of psychosis is delusion (1) with paranoid delusion (3), sometimes referred to as persecutory delusion (4) being the most common type. Paranoia is an important sign in many mental conditions, but may also occur in the public population $(4,5)$. Studies showed that almost $30 \%$ of people in the general population are paranoid $(6,7)$. Paranoia is the groundless threatening thoughts that other people intend to cause harm $(4,5)$ and can be delusions. This may be due to misinterpretation of interpersonal behaviors $(8)$ and lead to a sense of vulnerability (9). Frequent and persistent suspicions may adversely affect the performance (3) and the patient interacts less with others, prefers more isolation, quits activities (10), and might develop suicidal ideation (11). Though medications are still the mainstay of treatment of psychotic disorders, delusions, and level of functioning are not always cured by antipsychotics (12). Therefore, effective complementary treatments are yet needed to make a significant improvement (13).

Promising results have been achieved by targeted Cognitive behavioral therapy (CBT) for psychosis . These techniques, provoke and facilitate learning of safety within the feared situations (14-16). This leads to proper reactions and thus eliminate paranoia (13). However, for many patients with persecutory delusions, it is very tough to get into a stressful situation because of intense anxiety. The chance of practicing it in an ordinary situation is also reduced when patients are admitted to a hospital $(13,15)$. One solution is to use social situations in virtual reality (VR) that it is much easier for patients to access.

VR is a technology that digitally furnishes a 3D ambience (17). VR ranges from environments with complete immersion (in which individuals can physically interact with objects and virtual persons) to non-immersion levels (18). As VR produces responses resembling the real-world events (19, 20), it can be used to evaluate (21), understand the causes (22), and treat different health conditions (23). VR has been introduced as an effective treatment in a broad range of psychiatric disorders (24) including phobia (25), post-traumatic stress disorder (26), anxiety disorders (27), and paranoia (23).

VR provides valuable facts that give a better understanding of paranoia $(15,28)$ while providing an endurable situation for patients $(29)$. Experiences show that VR based therapies are time-saving (22) and improve patient-doctor relationship (30). Virtual social environments can prepare patients to learn the appropriate reaction before entering the real world (31). A recent systematic review by Rus-Calafell, Mar et al. shows that VR facilitates learning in new emotional and behavioral responses and can be used for social skills training (32).

In recent years, several reports have systematically reviewed the results of researches examining the effects of VR based treatments on various mental conditions. But, to our knowledge, there is a lack of systematic reviews evaluating studies using VR-based treatments for paranoia. Therefore, in this study, we aimed to: (1) investigate VR-based studies aiming to treat patients with paranoid and evaluate the efficacy, (2) identify features, technologies used and methods of providing VR-based interventions, (3) describe the limitations of existing studies (4), provide suggestions for future studies and practical recommendations for more effective VR-based interventions.

\section{Methods}

This study is a systematic review. The PICOS framework is used to recognize proper sources and search for related evidences to form a focused question and facilitate literature search. Within this framework, the population includes patients with paranoid disorder, intervention includes virtual reality therapy, comparison group includes routine therapy, non-VR-based treatment, pre-treatment VR-based, and untreated conditions, and outcome includes improvement symptoms of the disease.

\section{Literature search}

In order to collect data, a search was performed on 19/02/2020 in 5 important medical, health, and psychological databases including PubMed, Embase, Web of Science, PsycINFO, and Scopus. The search was performed without a time limit. Related sites and magazines were searched manually to ensure that all sources were identified. Also, references to all studies included in the study were manually searched to identify any additional studies that were not identified 
during the electronic database search. To update the results, a second search was performed on 20/07/2020. The keyword search strategy changed based on each database. Generally, the following keywords and search strategies were used:

(VR OR "Virtual Reality" OR "Virtual Realities" OR "Virtual environment" OR Simulation) AND (Paranoi* OR persecutory) AND (treat* OR therap*).

Then the results obtained from various sources were reviewed to remove duplicates and then entered into Endnote resource management software.

\section{Inclusion and exclusion criteria}

The inclusion and exclusion criteria were determined based on the defined PICOS. Inclusion criteria included studies that: (a) published in English, (b) included patients with paranoia or paranoid delusion, (c) were conducted for therapeutic purpose, (d) the intervention was based on virtual reality. Review articles, letters, abstracts, conferences, editorials, and notes were excluded as well as sources with no available full text.

\section{Study selection}

After removing duplicate references, screening was performed in two stages. In the first stage, titles and abstracts of the identified articles were reviewed to select relevant studies based on inclusion criteria. Then, in the second phase, two researchers separately reviewed the full text of articles that were identified according to the relevant criteria. Decisive agreement was made through discussion in terms of disagreement between scholars in the selection of articles.

\section{Quality assessment}

All the papers, regardless of the results of their methodological quality, underwent data extraction and synthesis due to the technical and developmental nature of the original papers. So we did not exclude studies that technically had good quality but did not meet the requirements of the checklists.

\section{Data extraction}

Selected studies were reviewed thoroughly and data were extracted by a researcher using the designed data extraction sheet and then verified by a second researcher. The chosen data were: Publication data (i.e., author, year, and country), aim of the study, study design, sample size, participant's data, technology used, scenario/avatar, methodology data, evaluation, and results.

\section{Results}

\section{Study selection}

The process of selecting articles, including the number of initial and screened studies, excluded studies, and eventually included studies, is summarized in Figure 1. Overall, 252 studies were identified: 41 articles from PubMed, 56 from Scopus, 97 from Embase, 54 from Web of Science, and 4 from PsyclNFO. After removing duplicates, and screening their title and abstract, 43 articles were selected for full-text review. Then conference abstracts, reviews, unrelated topics, and studies that did not report results were excluded. One more article that was not available as full text and no replies received from the authors was also excluded. Finally, 6 studies remained for the review.

\section{Characters of study}

The full Characters of included studies are shown in Table 1. From the included studies, three studies were conducted in the Netherlands, two in the UK and the other in Germany. Four studies were randomized controlled trials (RCTs) and two were pre-posttest studies. General aim was evaluating effectiveness of using virtual environments for reducing persecutory delusions and paranoia. The total sample in the included studies were 392 patients. The mean age of the samples in the five studies was about 39 years, except for one study that the age range was reported to be 20 to 36 years. 
Table 1

Summary characteristic of included studies in systematic review.

\begin{tabular}{|c|c|c|c|c|c|c|c|c|c|}
\hline \multirow{3}{*}{$\begin{array}{l}\text { Author, year, } \\
\text { Country }\end{array}$} & \multirow[t]{3}{*}{ Aim of study } & \multirow{3}{*}{$\begin{array}{l}\text { Study } \\
\text { design }\end{array}$} & \multirow{2}{*}{\multicolumn{2}{|c|}{ Sample size }} & \multicolumn{5}{|l|}{ Participants } \\
\hline & & & & & \multirow[t]{2}{*}{ Diagnosis } & \multicolumn{2}{|l|}{ Age } & \multicolumn{2}{|c|}{$\begin{array}{l}\text { Gender } \\
\text { (male/female) }\end{array}$} \\
\hline & & & experiment & control & & experiment & control & experiment & control \\
\hline $\begin{array}{l}\text { Geraets } \\
\text { et.al. } \\
2020 \\
\text { Netherlands } \\
(36)\end{array}$ & $\begin{array}{l}\text { Examined whether treatment with } \\
\text { VR-CBT for paranoia influences } \\
\text { momentary affective states, and } \\
\text { whether VR-CBT changes the } \\
\text { adverse interplay between affective } \\
\text { states and paranoia. }\end{array}$ & RCT & 43 & 48 & $\begin{array}{l}\text { Psychotic } \\
\text { disorder, } \\
\text { paranoid } \\
\text { ideations }\end{array}$ & 38.1 & 49.9 & $29 / 14$ & $34 / 14$ \\
\hline $\begin{array}{l}\text { Pot-Kolder } \\
\text { et.al. } \\
2020 \\
\text { Netherlands } \\
\text { (38) }\end{array}$ & $\begin{array}{l}\text { Determine the short-term cost- } \\
\text { effectiveness of VR-CBT. }\end{array}$ & RCT & 58 & 58 & $\begin{array}{l}\text { Patients with } \\
\text { a psychotic } \\
\text { disorder } \\
\text { suffering from } \\
\text { paranoid } \\
\text { ideation }\end{array}$ & 36.5 & 39.5 & $40 / 18$ & $42 / 16$ \\
\hline $\begin{array}{l}\text { Freeman } \\
\text { et.al. } \\
2016 \\
\text { UK (37) }\end{array}$ & $\begin{array}{l}\text { To test the hypothesis that VRCT } \\
\text { would lead to greater delusion } \\
\text { reduction than alone VR-exposure. }\end{array}$ & RCT & 15 & 15 & $\begin{array}{l}\text { Persecutory } \\
\text { delusions }\end{array}$ & 42.1 & 40.6 & $10 / 5$ & $6 / 9$ \\
\hline $\begin{array}{l}\text { Pot-Kolder } \\
\text { et al. } \\
2018 \\
\text { Netherlands } \\
\text { (35) }\end{array}$ & $\begin{array}{l}\text { Investigated the effects of VR-CBT } \\
\text { paranoid thoughts and social } \\
\text { participation. }\end{array}$ & RCT & 58 & 58 & $\begin{array}{l}\text { Psychotic } \\
\text { disorder with } \\
\text { paranoid } \\
\text { ideation in the } \\
\text { past month }\end{array}$ & 36.5 & 39.5 & $40 / 18$ & $42 / 16$ \\
\hline $\begin{array}{l}\text { Moritz et al. } \\
2014 \\
\text { Germany } \\
(33)\end{array}$ & $\begin{array}{l}\text { Evaluated a brief intervention aimed } \\
\text { to induce doubt and to decrease } \\
\text { delusions. }\end{array}$ & $\begin{array}{l}\text { Pre- } \\
\text { post } \\
\text { test }\end{array}$ & 33 & & Schizophrenia & $M=40.5$ & & $21 / 12$ & \\
\hline $\begin{array}{l}\text { Gega, et al. } \\
2013 \\
\text { UK (34) }\end{array}$ & $\begin{array}{l}\text { Explore the feasibility of the VE } \\
\text { system as a therapy tool for } \\
\text { patients who were recovering from } \\
\text { psychosis and who had residual } \\
\text { paranoia and comorbid social } \\
\text { anxiety }\end{array}$ & $\begin{array}{l}\text { Pre- } \\
\text { post } \\
\text { test }\end{array}$ & 6 & & $\begin{array}{l}\text { Paranoia and } \\
\text { social anxiety }\end{array}$ & 20 to 36 & & $6 / 0$ & \\
\hline
\end{tabular}

\section{Interventions}

The technology used in VR-based interventions to create a virtual environment includes tools for creating a situation, image and sound that are meant to enhance the sense of presence. A summary of the technology used in the reviewed studies is described in Table 2 . The most commonly used hardware was Head-Mounted Display (HMD), which was used in four studies. In one study, a speaker was used to produce the sound. A recording camera was used in one of them, and a room with specific dimensions was used to create a virtual environment. Unity3D was the most commonly used software. Designed scenarios included a variety of social environments with a number of human avatars. Interventions continued for 16 sessions in four studies, and 12 in one, lasting for one to two hours. One study did not explain about the number and duration of sessions. These sessions were mostly offered in hospitals and centers for mental health care.

After the first evaluation before the intervention, patients have been evaluated several times during treatment sessions. In four studies, evaluation was performed in three stages. In another study, pre- and post-intervention evaluations were performed. One study did not describe the exact timing of the assessments. Several items were evaluated with relevant tools, including distress, perceived social threat, thoughts, feelings, social contexts, momentary paranoia, persecution, patients' thoughts, and level of anxiety.

In almost all of the studies, the results show that VR-based interventions reduce paranoid thoughts, delusions and safety behaviors (33-36). The results of one study show that VR-CBT treatment is more effective than conventional therapy in improving the symptoms of feeling suspicious, disliked, hurt, and anxious (36). The results of two studies show a reduction in patients' anxiety $(34,35)$. And two studies show that patients found that they were safe from what they feared $(35,37)$. One study to evaluate the cost-effectiveness of VR-based interventions found that these interventions, in addition to increasing patients' social participation, were cost-effective (38). Details are described in Table 2. 
Table 2

Intervention characteristic of included studies in systematic review.

\begin{tabular}{|c|c|c|c|c|c|c|c|c|c|}
\hline \multirow{2}{*}{$\begin{array}{l}\text { Author, } \\
\text { year }\end{array}$} & \multicolumn{2}{|c|}{ Technology used } & \multirow{2}{*}{$\begin{array}{l}\text { Scenario } \\
\text { / Avatar }\end{array}$} & \multicolumn{3}{|c|}{ Methodology } & \multicolumn{3}{|l|}{ Evaluation } \\
\hline & Hardware & Software & & Sessions & $\begin{array}{l}\text { Duration } \\
\text { of the } \\
\text { sessions }\end{array}$ & $\begin{array}{l}\text { Place of the } \\
\text { session }\end{array}$ & $\begin{array}{l}\text { Evaluation } \\
\text { time }\end{array}$ & $\begin{array}{l}\text { Tests/ } \\
\text { scores used }\end{array}$ & Evaluation items \\
\hline $\begin{array}{l}\text { Geraets } \\
\text { et.al. } \\
2020\end{array}$ & $\begin{array}{l}\text { HMD[1], } \\
\text { Logitech } \\
\text { F310 Game } \\
\text { pad, Sony } \\
\text { HMZ, high- } \\
\text { definition } \\
\text { resolution } \\
\text { of } \\
1280 \times 720 \\
\text { per eye, } \\
51 \cdot 6 \\
\text { diagonal } \\
\text { field of } \\
\text { view, and a } \\
\text { 3DOF } \\
\text { tracker for } \\
\text { head } \\
\text { rotation. }\end{array}$ & $\begin{array}{l}\text { Vizard } \\
\text { software }\end{array}$ & $\begin{array}{l}\text { Street, bus, } \\
\text { café, } \\
\text { supermarket }\end{array}$ & 16 & $1 \mathrm{~h}$ & $\begin{array}{l}\text { seven } \\
\text { treatment } \\
\text { centers in } \\
\text { the } \\
\text { Netherlands }\end{array}$ & $\begin{array}{l}\text { 6-10 days } \\
\text { at } \\
\text { baseline, } \\
\text { post } \\
\text { treatment } \\
\text { and } 6 \\
\text { month } \\
\text { follow-u }\end{array}$ & $\begin{array}{l}\text { ESM[2], } \\
\text { ecological } \\
\text { momentary } \\
\text { assessment }\end{array}$ & $\begin{array}{l}\text { Paranoia(suspicious, } \\
\text { dislike, hurt), } \\
\text { negative affect } \\
\text { (anxious, insecure, } \\
\text { disappointed, lonely, } \\
\text { guilty, unsafe, } \\
\text { annoyed), positive } \\
\text { affect (cheerful, } \\
\text { enthusiastic, relaxed, } \\
\text { I like myself) }\end{array}$ \\
\hline $\begin{array}{l}\text { Pot- } \\
\text { Kolder } \\
\text { et.al. } \\
2020\end{array}$ & $\begin{array}{l}\text { HMD, } \\
\text { Logitech } \\
\text { F310 Game } \\
\text { pad, Sony } \\
\text { HMZ, high- } \\
\text { definition } \\
\text { resolution } \\
\text { of } \\
1280 \times 720 \\
\text { per eye, } \\
51 \cdot 6 \\
\text { diagonal } \\
\text { field of } \\
\text { view, and a } \\
3 D O F \\
\text { tracker for } \\
\text { head } \\
\text { rotation. }\end{array}$ & $\begin{array}{l}\text { Vizard } \\
\text { software }\end{array}$ & $\begin{array}{l}\text { Street, bus, } \\
\text { café, and } \\
\text { supermarket }\end{array}$ & 16 & $\begin{array}{l}0: 30-1 \\
h\end{array}$ & $\begin{array}{l}\text { seven } \\
\text { treatment } \\
\text { centers in } \\
\text { the } \\
\text { Netherlands }\end{array}$ & $\begin{array}{l}\text { At baseline } \\
\text { and at } 3 \\
\text { and } 6 \\
\text { months } \\
\text { post } \\
\text { baseline. }\end{array}$ & GPTS[3] & $\begin{array}{l}\text { Time spent with } \\
\text { others, } \\
\text { momentary anxiety, } \\
\text { momentary paranoia }\end{array}$ \\
\hline $\begin{array}{l}\text { Freeman } \\
\text { et.al. } \\
2016 .\end{array}$ & HMD & $\begin{array}{l}\text { Unity3D, } \\
\text { XVR }\end{array}$ & $\begin{array}{l}\text { Underground } \\
\text { train and lift/ } \\
\text { The } \\
\text { underground } \\
\text { scenarios } \\
\text { from no } \\
\text { avatar to } 22 \text {. } \\
\text { The lift } \\
\text { scenarios } \\
\text { from two } \\
\text { avatars to } 6 \text {. }\end{array}$ & 16 & $\begin{array}{l}1: 40 \\
2: 10^{-}\end{array}$ & $\begin{array}{l}\text { Patient's } \\
\text { home or } \\
\text { hospital }\end{array}$ & $\begin{array}{l}\text { Before and } \\
\text { During the } \\
\text { testing day }\end{array}$ & $\begin{array}{l}\text { Before( } \\
\text { PANSS[4], } \\
\text { PSYRATS[5], } \\
\text { the Safety } \\
\text { Behaviors } \\
\text { Questionnaire, } \\
\text { Persecutory } \\
\text { Beliefs, the } \\
\text { Beck Anxiety } \\
\text { Inventory, the } \\
\text { Beck } \\
\text { Depression } \\
\text { Inventory), } \\
\text { during test } \\
\text { (visual } \\
\text { analogue } \\
\text { rating scales) }\end{array}$ & Conviction, distress \\
\hline
\end{tabular}




\begin{tabular}{|c|c|c|c|c|c|c|c|c|c|}
\hline \multirow{2}{*}{$\begin{array}{l}\text { Author, } \\
\text { year }\end{array}$} & \multicolumn{2}{|c|}{ Technology used } & \multirow{2}{*}{$\begin{array}{l}\text { Scenario } \\
\text { / Avatar }\end{array}$} & \multicolumn{3}{|c|}{ Methodology } & \multicolumn{3}{|l|}{ Evaluation } \\
\hline & Hardware & Software & & Sessions & $\begin{array}{l}\text { Duration } \\
\text { of the } \\
\text { sessions }\end{array}$ & $\begin{array}{l}\text { Place of the } \\
\text { session }\end{array}$ & $\begin{array}{l}\text { Evaluation } \\
\text { time }\end{array}$ & $\begin{array}{l}\text { Tests/ } \\
\text { scores used }\end{array}$ & Evaluation items \\
\hline $\begin{array}{l}\text { Pot- } \\
\text { Kolder et } \\
\text { al. } \\
2018\end{array}$ & $\begin{array}{l}\text { HMD, } \\
\text { Logitech } \\
\text { F310 Game } \\
\text { pad, Sony } \\
\text { HMZ, high- } \\
\text { definition } \\
\text { resolution } \\
\text { of } \\
1280 \times 720 \\
\text { per eye, } \\
51 \cdot 6 \\
\text { diagonal } \\
\text { field of } \\
\text { view, and a } \\
\text { 3DOF } \\
\text { tracker for } \\
\text { head } \\
\text { rotation. }\end{array}$ & $\begin{array}{l}\text { Vizard } \\
\text { software }\end{array}$ & $\begin{array}{l}\text { Street, bus, } \\
\text { café, } \\
\text { supermarket/ } \\
\text { Therapists } \\
\text { could change } \\
\text { vary the } \\
\text { number of } \\
\text { human } \\
\text { avatars (0- } \\
\text { 40), the } \\
\text { characteristics } \\
\text { of the avatars } \\
\text { (including sex } \\
\text { and ethnicity), } \\
\text { and the } \\
\text { avatars' } \\
\text { responses to } \\
\text { the patient } \\
\text { (neutral or } \\
\text { hostile, eye } \\
\text { contact) to } \\
\text { match the } \\
\text { paranoid fears } \\
\text { of the patient, } \\
\text { therapists } \\
\text { could also } \\
\text { make the } \\
\text { avatars say } \\
\text { pre-recorded } \\
\text { sentences. }\end{array}$ & 16 & $1 \mathrm{~h}$ & $\begin{array}{l}\text { Seven } \\
\text { Dutch } \\
\text { mental } \\
\text { health } \\
\text { centers. }\end{array}$ & $\begin{array}{l}\text { At } \\
\text { baseline, } \\
\text { after } \\
\text { treatment } \\
\text { (3 months } \\
\text { from } \\
\text { baseline), } \\
\text { and at a } 6 \\
\text { month } \\
\text { follow-up } \\
\text { visit. }\end{array}$ & $\begin{array}{l}\text { Momentary } \\
\text { paranoia and } \\
\text { perceived } \\
\text { social threat } \\
\text { subscales. } \\
\text { Secondary } \\
\text { outcomes: the } \\
\text { safety } \\
\text { behavior } \\
\text { questionnaire, } \\
\text { persecutory } \\
\text { delusions, } \\
\text { GPTS, social } \\
\text { interaction } \\
\text { anxiety scale, } \\
\text { Beck } \\
\text { depression } \\
\text { inventory. } \\
\text { Functional } \\
\text { outcomes: } \\
\text { social and } \\
\text { occupational } \\
\text { functioning } \\
\text { assessment } \\
\text { scale } \\
\text { Manchester } \\
\text { short } \\
\text { assessment } \\
\text { of quality of } \\
\text { life, after the } \\
\text { fourth and } \\
\text { eighth } \\
\text { sessions, } \\
\text { presence in } \\
\text { virtual reality: } \\
\text { the Igroup } \\
\text { presence } \\
\text { questionnaire, } \\
\text { and cyber } \\
\text { sickness } \\
\text { symptoms } \\
\text { with the } \\
\text { simulator } \\
\text { sickness } \\
\text { questionnaire. }\end{array}$ & $\begin{array}{l}\text { Momentary } \\
\text { thoughts, feelings, } \\
\text { social contexts, } \\
\text { symptoms, } \\
\text { negative affect, } \\
\text { positive affect, } \\
\text { momentary } \\
\text { paranoia, and } \\
\text { perceived social } \\
\text { threat. }\end{array}$ \\
\hline $\begin{array}{l}\text { Moritz, } \\
\text { et al. } \\
2014\end{array}$ & $\begin{array}{l}\text { For the } \\
\text { noise } \\
\text { condition: } \\
\text { applied PC } \\
\text { speakers. }\end{array}$ & $\begin{array}{l}\text { Unity 3D, } \\
\text { artificial } \\
\text { characters: } \\
\text { 3D } \\
\text { modeling } \\
\text { software } \\
\text { DAZ-studio. } \\
\text { Body } \\
\text { animations: } \\
\text { (BVH[6]) } \\
\text { data from } \\
\text { the motion } \\
\text { capturing } \\
\text { procedure. }\end{array}$ & $\begin{array}{l}\text { Virtual street/ } \\
6 \text { different } \\
\text { avatars were } \\
\text { created, each } \\
\text { showed a } \\
\text { neutral, angry } \\
\text { or happy face, } \\
\text { and the } \\
\text { participant } \\
\text { only met one } \\
\text { avatar at a } \\
\text { time }\end{array}$ & - & - & $\begin{array}{l}\text { In- and } \\
\text { outpatient } \\
\text { facilities of } \\
\text { two } \\
\text { psychiatric } \\
\text { hospitals in } \\
\text { Hamburg }\end{array}$ & $\begin{array}{l}\text { Before and } \\
\text { after the } \\
\text { experiment }\end{array}$ & $\begin{array}{l}\text { Paranoia } \\
\text { Checklist, } \\
\text { POD[7] }\end{array}$ & $\begin{array}{l}\text { The degree to which } \\
\text { subjects } \\
\text { remembered the } \\
\text { identity, location and } \\
\text { effect of each of the } \\
\text { pedestrians. }\end{array}$ \\
\hline
\end{tabular}




\begin{tabular}{|c|c|c|c|c|c|c|c|c|c|}
\hline \multirow{2}{*}{$\begin{array}{l}\text { Author, } \\
\text { year }\end{array}$} & \multicolumn{2}{|c|}{ Technology used } & \multirow{2}{*}{$\begin{array}{l}\text { Scenario } \\
\text { / Avatar }\end{array}$} & \multicolumn{3}{|c|}{ Methodology } & \multicolumn{3}{|l|}{ Evaluation } \\
\hline & Hardware & Software & & Sessions & $\begin{array}{l}\text { Duration } \\
\text { of the } \\
\text { sessions }\end{array}$ & $\begin{array}{l}\text { Place of the } \\
\text { session }\end{array}$ & $\begin{array}{l}\text { Evaluation } \\
\text { time }\end{array}$ & $\begin{array}{l}\text { Tests/ } \\
\text { scores used }\end{array}$ & Evaluation items \\
\hline $\begin{array}{l}\text { Gega, et } \\
\text { al. } \\
2013\end{array}$ & $\begin{array}{l}15^{\star} 15 \\
\text { meters } \\
\text { portable } \\
\text { booth } \\
\text { a video- } \\
\text { processing } \\
\text { unit with a } \\
\text { camera } \\
\text { linked to a } \\
\text { computer } \\
\text { and video } \\
\text { recorder, a } \\
\text { screen } \\
\text { monitor, } \\
\text { and an } \\
\text { adjustable } \\
\text { sitting stool }\end{array}$ & camera & $\begin{array}{l}\text { One hundred } \\
\text { specially } \\
\text { video clips } \\
\text { that last 2-10 } \\
\text { minutes and } \\
\text { depict a } \\
\text { variety of } \\
\text { social } \\
\text { situations/ } \\
\text { The } \\
\text { characters in } \\
\text { these } \\
\text { situations } \\
\text { could be } \\
\text { hostile, rude, } \\
\text { neutral or } \\
\text { friendly. Some } \\
\text { characters ask } \\
\text { innocuous } \\
\text { questions or } \\
\text { personal } \\
\text { questions. }\end{array}$ & 12 & $1 \mathrm{~h}$ & - & $\begin{array}{l}\text { At baseline } \\
\text { (week 0), } \\
\text { at } 12 \text { and } \\
24 \text { week }\end{array}$ & $\begin{array}{l}\text { Persecution } \\
\text { (GPTS, beliefs } \\
\text { about self } \\
\text { and others } \\
\text { (BCSS[8]), } \\
\text { social anxiety } \\
\text { (Social } \\
\text { interaction } \\
\text { anxiety scale) }\end{array}$ & $\begin{array}{l}\text { Persecution, } \\
\text { patients thought, } \\
\text { anxiety rating }\end{array}$ \\
\hline
\end{tabular}

\section{Discussion}

The aim of this systematic review was to investigate the effect of using VR in the treatment of patients with paranoia or paranoid delusions. Studies have shown that patients with paranoia feel interacted in the VR environment and experience thoughts of persecution (39). According to previous studies, VR-based interventions have been acceptable and effective in improving mental illnesses (40).

Paranoid patients often have suspicious thoughts in social situations and in dealing with people. Anxiety is also one of the main symptom in these people (41). The use of VR has various purposes in the treatment of patients with paranoid, including eliminating the paranoid thoughts, reducing social anxiety, increasing community participation, and changing their negative beliefs about themselves and others. Ultimately patients should believe that they are safe from what they are afraid of, and thoughts of suspicion about people are wrong. Therefore, the aim of the reviewed studies here, was to investigate the effect of VR-based interventions for improving the symptoms of the disorder (33-38). One study evaluated paranoia, as well as positive and negative affects and showed a decrease in paranoia and negative affects, but no significant effect on positive mental state (36).

VR technology provides many features to increase people's sense of immersion, especially in programs that focus on treating social anxiety disorders. To this end, avatars were designed to be more realistic and sociable in order to better communicate with patients (42). The same happens for patients with paranoia. VR provides a safe environment for the patient, and allows therapists and researchers to accurately identify the paranoid symptoms that may arise as a result of exposure. Different hardware and software are used to create a virtual environment. Head-mounted display and 3DOF tracker have been used to move in the laboratory environments. In a study that has used a camera to create an environment, a $15 \times 15$-meter portable room with a variety of equipment has been used including seating area, screen and etc. Various softwares are also used to design virtual reality, of which Unity3D is more common. In studies that used Unity3D, XVR and Vizard software to design virtual reality, few scenarios were created. In one study, a camera was used to create a virtual environment that allowed the recording of several video clips from different social situations. The expense of the equipment, and lack of VR specialists, especially for the mentally ill, has limited the practice (25). This is reflected in the partially low number of studies we could include. Though this might change when more evidences are provided about the effectiveness.

Different scenarios have been designed as the social environment in which the patient might get involved in the daily life. For example, in one study, patients were asked to walk on a virtual street, which was conducted in two phases, including a practice trial and two experimental trials. The walk was about 250 meters, with a corner changing the direction in the midway, and finally ends when turning left (33). Scenarios are logically designed based on the nature of the target symptom, and range from starting a conversation for improving social skills of patients with autism (43).

Three of the reviewed studies were conducted by a same team, with similar technology, scenarios and intervention method. A cost-effectiveness analysis was added to the newest. Accordingly, this intervention improves social participation, reduces paranoid ideation and social anxiety. Although the VR technologies are expensive, the intervention is cost-effective in a long-term follow-up $(35,36,38)$.

A recent systematic review concluded that VR based treatments are effective interventions for psychosocial remediation in schizophrenia (44). Majority have used non-immersion environments making it possible to create the desired setting and avatars that interact with patients, though immersion environments might be the one step beyond. Though the review is not determining, except for one study which states that some patients did not consider VR environments to be real. While being aware of virtual nature of the environment might reduce patients' anxiety, sufficient immersion is needed to create a strong sense of presence and emotional engagement that is necessary for a successful treatment (34). 
The limitations mentioned by the reviewed studies are related to the momentary evaluations of the interventions, and the limited number of scenarios. Despite evidence for cost-effectiveness, the high cost of the technology is one of the obstacles to widespread use, and long-term review is needed for a conclusion (37, 38). Moreover, results of two studies are limited by the absence of a control group $(34,35)$. The fact that some patients (probably with deeper psychopathology) might be afraid to participate is also limiting generalizability of the results (33). Finally, the number of studies is small, though they show promising effect of VR-based interventions for improving paranoia.

Studies can address the limitations mentioned above by a larger sample size, comparing the results to a control group and considering a longer follow up duration. It might be noteworthy to include effect of gender, and duration of the disorder. Manifestation of psychiatric symptoms is influenced by several psychological factors. Experience of the reviewed studies indicate that measuring different psychological factors might give a better understanding of etiology as well as deeper insight to effect of the VR-based intervention. A good example might be the comprehensive approach for understanding the cognitive and behavioral components of how a patient reacts to the environmental stimuli, than includes coping styles, mental states, personality characteristics, cognitive ability as well as details of the VR environment. Application of VR-based interventions within different social context and using suitable scenarios, might provide more interesting findings as well.

This study has some limitations. One common limitation for all systematic review studies is the bias in the selection of articles, therefore the search strategy was planned to include all of studies in this field. Though only papers published in English were included. We could not succeed to reach the full text of one study as described before.

\section{Conclusion}

This review shows that VR-based interventions are effective for treatment of patients with paranoia. Although the use of VR technology is limited for a variety of reasons, including cost, this type of intervention is more attractive than conventional interventions. VR-based interventions improve symptoms in patients with paranoid delusions, increase patients' social participation, reduce stress and suspiciousness. Moreover, it provides a better control of treatment sessions for therapists.

\section{Abbreviations}

VR: Virtual Reality

VR-CBT: Virtual Reality based-Cognitive Behavioral Therapy

VE: Virtual Environment

RCT: Randomize Controlled Trial

HMD: Head-Mounted Display

ESM: Experience Sampling Method

GPTS: Green's Paranoid Thoughts Scale

PANSS: Positive and Negative Syndrome Scale

PSYRATS: the Psychotic Symptoms Rating Scale

BCSS: Brief Core Schema Scales

\section{Declarations}

\section{Ethics approval and consent to participate}

The study is approved by ethical committee of Tabriz university of medical sciences (IR.TBZMED.REC.1399.584).

\section{Consent for publication}

Not applicable.

\section{Availability of data and material}

All data generated or analyzed during this study are included in this article.

\section{Competing interests}

None. 


\section{Funding}

None.

\section{Authors' Contributions}

TS: Conceptualization, Methodology, supervision; EM: Data curation, Writing- Original draft preparation. SF: Validation, investigation, Writing and Editing. All read and approved the final draft and agreed for submission.

\section{Acknowledgements}

This research was a part of an MSc thesis that supported by Tabriz University of Medical Sciences. Authors would like to thank the support of clinical research development unit, Razi hospital.

\section{Authors' Information}

1: Department of Health Information Technology, School of Management and Medical Informatics, Tabriz University of Medical Sciences, Tabriz, Iran. 2: University of Groningen, University medical center Groningen, University Center for Psychiatry, Rob Giel research center, Groningen. The Netherlands. ${ }^{3:}$ Research Center of Psychiatry and Behavioral Sciences, Tabriz University of Medical Sciences, Tabriz, Iran.

\section{References}

1. Heckers S, Barch DM, Bustillo J, Gaebel W, Gur R, Malaspina D, Owen MJ, Schultz S, Tandon R, Tsuang M, Van Os J. Structure of the psychotic disorders classification in DSM-5. Schizophrenia research. 2013 Oct 1;150(1):11-4.

2. Howes OD, Murray RM. Schizophrenia: an integrated sociodevelopmental-cognitive model. The Lancet. 2014;383(9929):1677-87.

3. Bird JC, Evans R, Waite F, Loe BS, Freeman D. Adolescent paranoia: prevalence, structure, and causal mechanisms. Schizophrenia bulletin. 2019;45(5):1134-42.

4. Freeman D. Persecutory delusions: a cognitive perspective on understanding and treatment. The Lancet Psychiatry. 2016;3(7):685-92.

5. Meisel SF, Garety PA, StahI D, Valmaggia LR. Interpersonal processes in paranoia: a systematic review. Psychological medicine. 2018;48(14):2299-312.

6. Freeman D, McManus S, Brugha T, Meltzer H, Jenkins R, Bebbington P. Concomitants of paranoia in the general population. Psychological medicine. 2011;41(5):923-36.

7. Bebbington PE, McBride O, Steel C, Kuipers E, Radovanoviĉ M, Brugha T, et al. The structure of paranoia in the general population. The British Journal of Psychiatry. 2013;202(6):419-27.

8. Freeman D, Garety PA, Bebbington PE, Smith B, Rollinson R, Fowler D, et al. Psychological investigation of the structure of paranoia in a non-clinical population. The British Journal of Psychiatry. 2005;186(5):427-35.

9. Riches S, Garety P, Rus-Calafell M, Stahl D, Evans C, Sarras N, et al. Using virtual reality to assess associations between paranoid ideation and components of social performance: A pilot validation study. Cyberpsychology, Behavior, and Social Networking. 2019;22(1):51-9.

10. Freeman D. Suspicious minds: the psychology of persecutory delusions. Clinical psychology review. 2007;27(4):425-57.

11. Collett N, Pugh K, Waite F, Freeman D. Negative cognitions about the self in patients with persecutory delusions: An empirical study of self-compassion, self-stigma, schematic beliefs, self-esteem, fear of madness, and suicidal ideation. Psychiatry research. 2016;239:79-84.

12. Moutoussis M, Williams J, Dayan P, Bentall RP. Persecutory delusions and the conditioned avoidance paradigm: towards an integration of the psychology and biology of paranoia. Cognitive neuropsychiatry. 2007;12(6):495-510.

13. Freeman D, Lister R, Waite F, Yu L-M, Slater M, Dunn G, et al. Automated psychological therapy using virtual reality (VR) for patients with persecutory delusions: study protocol for a single-blind parallel-group randomised controlled trial (THRIVE). Trials. 2019;20(1):87.

14. Lincoln TM, Peters E. A systematic review and discussion of symptom specific cognitive behavioural approaches to delusions and hallucinations. Schizophr Res. 2019;203:66-79.

15. Freeman D, Reeve S, Robinson A, Ehlers A, Clark D, Spanlang B, et al. Virtual reality in the assessment, understanding, and treatment of mental health disorders. Psychological medicine. 2017;47(14):2393-400.

16. Valmaggia LR, Day F, Garety P, Freeman D, Antley A, Slater M, et al. Social defeat predicts paranoid appraisals in people at high risk for psychosis. Schizophrenia research. 2015;168(1-2):16-22.

17. Slater M, Sanchez-Vives MV. Enhancing our lives with immersive virtual reality. Frontiers in Robotics and Al. 2016;3:74.

18. Miller HL, Bugnariu NL. Level of immersion in virtual environments impacts the ability to assess and teach social skills in autism spectrum disorder. Cyberpsychology, Behavior, and Social Networking. 2016;19(4):246-56.

19. Sanchez-Vives MV, Slater M. From presence to consciousness through virtual reality. Nature Reviews Neuroscience. 2005;6(4):332-9.

20. Slater M, Rovira A, Southern R, Swapp D, Zhang JJ, Campbell C, et al. Bystander responses to a violent incident in an immersive virtual environment. PloS one. $2013 ; 8(1)$. 
21. Wen D, Lan X, Zhou Y, Li G, Hsu S-H, Jung T-P. The study of evaluation and rehabilitation of patients with different cognitive impairment phases based on virtual reality and EEG. Frontiers in aging neuroscience. 2018;10:88.

22. Freeman D, Slater M, Bebbington PE, Garety PA, Kuipers E, Fowler D, et al. Can virtual reality be used to investigate persecutory ideation? The Journal of nervous and mental disease. 2003;191(8):509-14.

23. Veling W, Pot-Kolder R, Counotte J, van Os J, van der Gaag M. Environmental social stress, paranoia and psychosis liability: a virtual reality study. Schizophrenia Bulletin. 2016;42(6):1363-71.

24. Jarrold W, Mundy P, Gwaltney M, Bailenson J, Hatt N, McIntyre N, et al. Social attention in a virtual public speaking task in higher functioning children with autism. Autism Research. 2013;6(5):393-410.

25. Botella C, Fernández-Álvarez J, Guillén V, García-Palacios A, Baños R. Recent progress in virtual reality exposure therapy for phobias: a systematic review. Current psychiatry reports. 2017;19(7):42.

26. Deng W, Hu D, Xu S, Liu X, Zhao J, Chen Q, et al. The efficacy of virtual reality exposure therapy for PTSD symptoms: A systematic review and metaanalysis. Journal of affective disorders. 2019.

27. Opriş D, Pintea S, García-Palacios A, Botella C, Szamosközi Ş, David D. Virtual reality exposure therapy in anxiety disorders: a quantitative meta-analysis. Depression and anxiety. 2012;29(2):85-93.

28. Freeman D, Pugh K, Antley A, Slater M, Bebbington P, Gittins M, et al. Virtual reality study of paranoid thinking in the general population. The British Journal of Psychiatry. 2008;192(4):258-63.

29. Valmaggia LR, Freeman D, Green C, Garety P, Swapp D, Antley A, et al. Virtual reality and paranoid ideations in people with an 'at-risk mental state'for psychosis. The British Journal of Psychiatry. 2007;191(S51):s63-s8.

30. Pandita S, Won AS. Clinical applications of virtual reality in patient-centered care. Technology and Health: Elsevier; 2020. p. $129-48$.

31. McManus F, Sacadura C, Clark DM. Why social anxiety persists: An experimental investigation of the role of safety behaviours as a maintaining factor. Journal of behavior therapy and experimental psychiatry. 2008;39(2):147-61.

32. Rus-Calafell M, Garety P, Sason E, Craig TJ, Valmaggia LR. Virtual reality in the assessment and treatment of psychosis: a systematic review of its utility, acceptability and effectiveness. Psychological medicine. 2018;48(3):362-91.

33. Moritz S, Voigt M, Köther U, Leighton L, Kjahili B, Babur Z, et al. Can virtual reality reduce reality distortion? Impact of performance feedback on symptom change in schizophrenia patients. J Behav Ther Exp Psychiatry. 2014;45(2):267-71.

34. Gega L, White R, Clarke T, Turner R, Fowler D. Virtual environments using video capture for social phobia with psychosis. Cyberpsychol Behav Soc Netw. 2013;16(6):473-9.

35. Pot-Kolder R, Geraets CNW, Veling W, van Beilen M, Staring ABP, Gijsman HJ, et al. Virtual-reality-based cognitive behavioural therapy versus waiting list control for paranoid ideation and social avoidance in patients with psychotic disorders: a single-blind randomised controlled trial. Lancet Psychiatry. 2018;5(3):217-26.

36. Geraets CNW, Snippe E, van Beilen M, Pot-Kolder R, Wichers M, van der Gaag M, et al. Virtual reality based cognitive behavioral therapy for paranoia: Effects on mental states and the dynamics among them. Schizophr Res. 2020.

37. Freeman D, Bradley J, Antley A, Bourke E, DeWeever N, Evans N, et al. Virtual reality in the treatment of persecutory delusions: randomised controlled experimental study testing how to reduce delusional conviction. Br J Psychiatry. 2016;209(1):62-7.

38. Pot-Kolder R, Veling W, Geraets C, Lokkerbol J, Smit F, Jongeneel A, et al. Cost-Effectiveness of Virtual Reality Cognitive Behavioral Therapy for Psychosis: Health-Economic Evaluation Within a Randomized Controlled Trial. J Med Internet Res. 2020;22(5).

39. Fornells-Ambrojo M, Barker C, Swapp D, Slater M, Antley A, Freeman D. Virtual reality and persecutory delusions: safety and feasibility. Schizophr Res. 2008;104(1-3):228-36.

40. Rus-Calafell M, Garety P, Sason E, Craig TJK, Valmaggia LR. Virtual reality in the assessment and treatment of psychosis: a systematic review of its utility, acceptability and effectiveness. Psychol Med. 2018;48(3):362-91.

41. Lee R. Mistrustful and Misunderstood: A Review of Paranoid Personality Disorder. Curr Behav Neurosci Rep. 2017;4(2):151-65.

42. Oing T, Prescott J. Implementations of Virtual Reality for Anxiety-Related Disorders: Systematic Review. JMIR Serious Games. $2018 ; 6(4):$ e10965.

43. Mesa-Gresa P, Gil-Gómez H, Lozano-Quilis JA, Gil-Gómez JA. Effectiveness of Virtual Reality for Children and Adolescents with Autism Spectrum Disorder: An Evidence-Based Systematic Review. Sensors (Basel). 2018;18(8).

44. Fernández-Sotos P, Fernández-Caballero A, Rodriguez-Jimenez R. Virtual reality for psychosocial remediation in schizophrenia: a systematic review. The European Journal of Psychiatry. 2020;34(1):1-1.

\section{Figures}




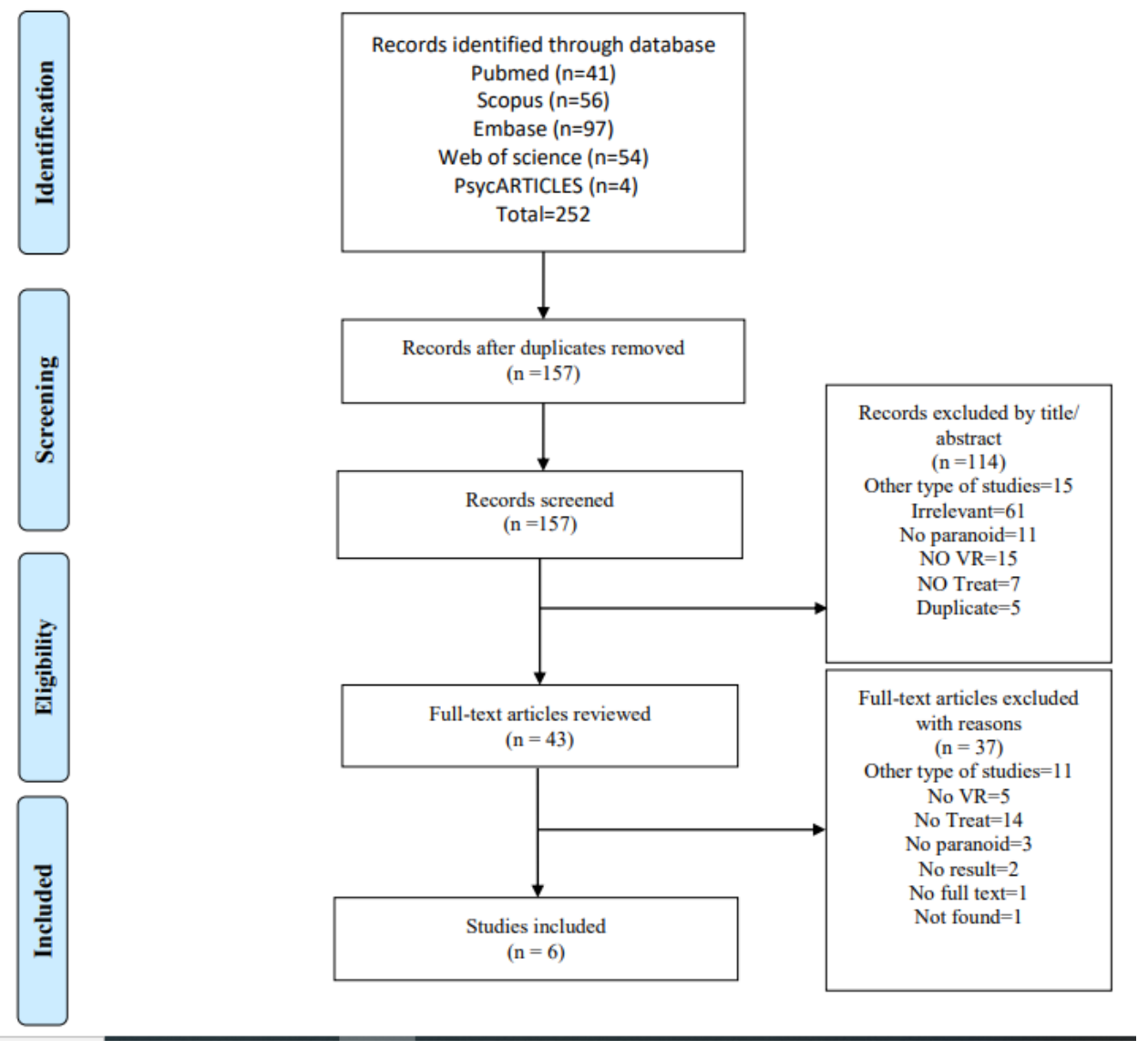

Figure 1

PRISMA flow diagram illustrating study selection. 